\title{
Measures against cattle's mono- and mixtinvasions with fasciolosis and strongylatoses of the gastrointestinal tract
}

\author{
Ekaterina Klimova $^{1 *}$, Manya Mkrtchyan $^{2}$, Tatyana Babintseva ${ }^{1}$, Alexandra Reshetnikova ${ }^{1}$, and Yuliya Kurskaya $^{3}$ \\ ${ }^{1}$ Izhevsk State Agricultural Academy, Izhevsk 426069, Russia \\ ${ }^{2}$ St. Petersburg State Academy of Veterinary Medicine, St. Petersburg 196084, Russia \\ ${ }^{3}$ Smolensk State Agricultural Academy, Smolensk 214000, Russia
}

\begin{abstract}
In the farms of the Udmurt Republic, the most common endoparasites of cattle are Fasciola hepatica, Chabertia ovina and Haemonchus contortus and their association. Feces samples were taken individually and examined by flotation and sequential swabs. The therapeutic efficacy of anthelmintic drugs has been studied in 780 cows. Animals' infection rate was determined by triple helminthocoproovoscopic examination of fecal samples by flotation and sequential washing before and after antiparasitic treatments (15, 30 and 90 days after deworming). The high degree of cattle infection in various regions of the Udmurt Republic with fasciolosis and strongilatosis of the gastrointestinal tract is due to optimal climatic conditions for the regular transmission of the pathogen to susceptible animals. The therapeutic efficacy of anthelmintic drugs has been studied in 675 cows, which were divided according to the principle of analogues into groups consisting of 45 animals. According to the results of our studies in case of nematode monoinvasion, the most effective antiparasitic drugs are closanthin $20 \%$ (the cost of one dose per animal is 77 rubles) and ivermectins (the cost of deworming per animal does not exceed 40 rubles). Analyzing the extenseffectivity of the studied anthelmintic drugs, we found that closantin $20 \%$ at a dose of 1 is the optimal drug in terms of efficacy and cost for monoinvasions (ID - $100 \%$ ) with fasciola or strongilates of the gastrointestinal tract, and their association (ID $-93.3 \%), 1.25 \mathrm{ml} / 50 \mathrm{~kg}$ of animal weight.
\end{abstract}

\section{Introduction}

In order to implement the Federal Law "On the Development of Agriculture", the Government of the Russian Federation has been given the task to increase the productivity of animal husbandry, and obtaining of quality products simultaneously. Animal husbandry's profitability directly depends on small number of invasive diseases, since they cause significant economical damage to livestock breeding by reducing the productivity and quality of the resulting products, as well as reducing breeding value and increasing the cost of comprehensive methods to combat parasitosis [1,2].

In the farms of the Udmurt Republic, the most common endoparasites of cattle are Fasciola hepatica, Chabertia ovina and Haemonchus contortus $[1,3]$.

During the planning of animal's deworming, it is necessary to take into account that as a result of complex methods to combat parasites of cattle, it is necessary to achieve complete elimination of helminths, and their metabolic products from the host organism. The choice, in this case, should be based not only on high effectiveness but also on the safety of drugs, which, in most cases, are quite toxic. Currently, over 2.000 anthelmintic drugs are used in world veterinary practice in different dosage forms [1, 3-10].
Taking into account the above, we consider the search of the most highly effective, low-toxic and costeffective antiparasitic agents with trematocidal and nematicidal effects to be an urgent issue.

\section{Materials and methods}

The distribution of fascioliasis and strongilatoses of the cattle's gastrointestinal was studied in 2016-2019 in the breeding farms of Votkinsk, Grakhovsk, Kez, Malopurginsky, Uvinsky districts of the Udmurt Republic. The research material was fecal samples from spontaneously infected animals. Thus, we examined 780 cows. The degree of animals' contamination was determined by conventional coproovoscopic methods and incomplete helminthological dissection of the liver and intestines of animals at slaughterhouses. Feces samples were taken individually and examined by flotation and sequential swabs. The therapeutic efficacy of anthelmintic drugs has been studied in 675 cows. The anthelmintic efficacy of drugs in production conditions was determined on the basis of coproovoscopic studies. Before massive deworming, each drug was tested in a small group of animals (5-10 heads). In the absence of complications, treatment of the entire group was started within 3 days.

Corresponding author: catia.calinina2012@yandex.ru 
The first series of experiments were carried out on animals spontaneously infected with fasciola. 6 groups of cows were formed for this: the first group was dewormed with the Klosantine $20 \%$ at a dose of $1.25 \mathrm{ml} / 50 \mathrm{~kg}$; the second group was dewormed with Alvet- granules $(3.75 \mathrm{~g} / 100 \mathrm{~kg})$. In all the rest groups, injectable drugs were used: in the third, Closaverm at the rate of $1 \mathrm{ml}$ per $50 \mathrm{~kg}$ of weight; the fourth group was injected with Santomectin in an identical dose; cows of the fifth group were treated with Albendozole in a dose of $15 \mathrm{ml}$ per $50 \mathrm{~kg}$ of weight. Animals of the sixth group were infected but did not undergo deworming, since they served as a control group.

The second series of experiment was carried out on animals spontaneously infected with gastrointestinal strangulates. The animals of the first group were given Alben tablets at a dose of 1 tablet per $35 \mathrm{~kg}$, animals from the following groups were injected with drugs: Klosanthin $20 \%-1.25 \mathrm{ml}$ per $50 \mathrm{~kg}$, Ivermec and Novomek $1 \mathrm{ml} / 50 \mathrm{~kg}$ and Albendozole $(15 \mathrm{ml} / 50 \mathrm{~kg})$. Animals of the sixth group did not receive antiparasitic drugs - it was a control group.

In the third series of experiments, animals infected with an association of parasites: fasciolas and gastrointestinal strictilates participated. For the purpose of deworming, two medications of a wide spectrum were used in accordance with the instructions; both of them have thromatocidal and nematicidal effect: Klosanthin $20 \%$ and Albendozole in mentioned doses.

Animals' infection rate was determined by triple helminthocoproovoscopic examination of fecal samples by flotation and sequential washing before and after antiparasitic treatments $(15,30$ and 90 days after deworming).

The invasion's extension level was also determined by the results of a partial helminthological dissection of the liver and intestines.

\section{Results}

In the Udmurt Republic, there are all the necessary favorable climatic conditions for the completion of the biological cycle of cattle helminths, particularly for fasciolas and strongilates of the gastrointestinal tract.

During the analysis of our research results (table 1), we found that in the studied areas, mono-invasions of fascioliasis and strongilatoses of the gastrointestinal tract and their associations were recorded.

Among monoinvasions, the dominant position is taken by strongilatoses of the gastrointestinal tract. The degree of infection is ranged from 33.07 to $59.59 \%$. The high degree of invasion can be explained by the fact that, firstly: the population of adult animals (cows, heifers) in the strongilates epizootic process is gastrointestinal tract as the primary source of invasion pathogen, and secondly: the biological cycle of the pathogen depends on conditions of environment, which are quite favorable for geohelminthes in the Republic.

Cattle's infection by fasciola on the examined regions' territory is due to the constantly acting regular transmission of the pathogen in this animal species. A significant number of waterlogged pastures, flood meadows, and prolonged positive ambient temperatures contribute to the development and spread of an intermediate host - a Limnea truncatula. The most favorable climatic conditions for the development of $F$. hepatica were observed in the central Uvinsky region, where the invasion intensity reaches up to $49.22 \%$. The smallest percentage of adult livestock infection $(16.77 \%)$ has been recorded in the northern Kez district of the Udmurt Republic, which proves that even a slight decrease in ambient temperature adversely affects the fasciola's development.

Table 1. Infestation degree of cattle in various areas of the UR.

\begin{tabular}{|c|c|c|c|}
\hline Region title & $\begin{array}{c}\text { The number of } \\
\begin{array}{c}\text { examined } \\
\text { animals }\end{array} \\
\end{array}$ & $\begin{array}{c}\begin{array}{c}\text { The number } \\
\text { of infected } \\
\text { animals }\end{array} \\
\end{array}$ & $\begin{array}{c}\text { The infestation } \\
\text { degree (ID), } \\
\%\end{array}$ \\
\hline \multicolumn{4}{|c|}{ Fasciolosis } \\
\hline Malopurginsky & 146 & 63 & 43.15 \\
\hline Uvinsky & 193 & 95 & 49.22 \\
\hline Votkinsk & 153 & 44 & 28.76 \\
\hline Kez & 161 & 27 & 16.77 \\
\hline Grakhovsk & 127 & 34 & 26.77 \\
\hline \multicolumn{4}{|c|}{ Strongilatoses of the cattle's gastrointestinal tract } \\
\hline Malopurginsky & 146 & 87 & 59.59 \\
\hline Uvinsky & 193 & 36 & 18.65 \\
\hline Votkinsk & 153 & 91 & 59.48 \\
\hline Kez & 161 & 53 & 32.92 \\
\hline Grakhovsk & 127 & 42 & 33.07 \\
\hline \multicolumn{4}{|c|}{$\begin{array}{c}\text { Fasciolosis }+ \text { Strongilatoses of the cattle's } \\
\text { gastrointestinal tract }\end{array}$} \\
\hline Malopurginsky & 146 & 32 & 21.92 \\
\hline Uvinsky & 193 & 37 & 19.27 \\
\hline Votkinsk & 153 & 27 & 17.65 \\
\hline $\mathrm{Kez}$ & 161 & 9 & 5.59 \\
\hline Grakhovsk & 127 & 15 & 11.81 \\
\hline
\end{tabular}

In case of association between fasciola and strongilates of the gastrointestinal tract, there was a slightly different picture: the minimum percentage of infection was observed in the northern Kes region and amounted to $5.59 \%$, and the largest number of infected animals (almost $22 \%$ ) was in the southern Malopurginsky district.

In parallel with coprological studies, an incomplete helminthological dissection of carcasses of animals, infected with fasciola and strongilates of the digestive tract was performed. When examining the liver of cattle, the following was recorded: an increase of the liver volume, dilation of the bile ducts, their wall was tightened, and a thick yellow-green liquid with a large number of parasites was released when they were cut. During a helminthological study of the gastrointestinal tract of cattle catarrhal-hemorrhagic inflammation of the abomasum and small intestine was noted.

In addition to efficiency the requirement of low price for anthelmintic drugs is significant for agricultural enterprises. Table 2 shows the drugs and their costs, which helps in the choice of the best-priced drugs.

To evaluate anthelmintic efficacy of the medicines, 5 experimental groups of animals were treated with one of the above drugs (table 3 ). 
Table 2. Comparative characteristics of anthelmintic drugs recommended for cattle infected with fasciola.

\begin{tabular}{|c|c|c|c|}
\hline $\begin{array}{c}\text { The name of } \\
\text { the drug }\end{array}$ & Doze & Cost & $\begin{array}{c}\text { Cost of } \\
1 \text { dose }\end{array}$ \\
\hline \multicolumn{4}{|c|}{ A wide-spectrum medication } \\
\hline $\begin{array}{c}\text { Klosanthin } 20 \\
\%\end{array}$ & $1.25 \mathrm{ml} / 50 \mathrm{~kg}$ & $100 \mathrm{ml}-685 \mathrm{rub}$ & $77 \mathrm{rub}$ \\
\hline $\begin{array}{c}\text { Alben } \\
\text { granules }\end{array}$ & $3.75 \mathrm{~g} / 100 \mathrm{~kg}$ & $500 \mathrm{~g}-580 \mathrm{rub}$ & $20 \mathrm{rub}$ \\
\hline Closaverm & $1 \mathrm{ml} / 50 \mathrm{~kg}$ & $100 \mathrm{ml}-430 \mathrm{rub}$ & $39 \mathrm{rub}$ \\
\hline Santomectin & $1 \mathrm{ml} / 50 \mathrm{~kg}$ & $50 \mathrm{ml}-296 \mathrm{rub}$ & $53 \mathrm{rub}$ \\
\hline Albendozole & $15 \mathrm{ml} / 50 \mathrm{~kg}$ & $11 .-625 \mathrm{rub}$ & $84 \mathrm{rub}$ \\
\hline
\end{tabular}

The results of the studies showed that already on the 15th day of the research, the degree of invasion with fasciola decreased significantly in all treated groups, but the maximum was in groups №3 and №4, where the drug's infestation degree was more than $93 \%$ and $95 \%$, respectively. At the same time, it must be pointed out that 1.5 months after deworming, fasciola's eggs were not found in animals of the first, third and fourth groups.

Farms of the Udmurt Republic are permanently dysfunctional for strongilates of the gastrointestinal tract. Therefore, one of the paramount tasks is the choice of not expensive and effective medicine (table 4).

The treatment of animals infected with monoinvasion strongilates was performed once with one of the above drugs (table 5).

Table 3. Infestation degree of cattle infected with fasciola after deworming $(n=45)$.

\begin{tabular}{|c|c|c|c|c|c|c|c|}
\hline \multirow[b]{3}{*}{$\begin{array}{c}\text { Group } \\
\text { № }\end{array}$} & \multirow[b]{3}{*}{ Drug name } & \multicolumn{6}{|c|}{ Research time, days } \\
\hline & & \multicolumn{2}{|c|}{ 15-th } & \multicolumn{2}{|c|}{ 30-th } & \multicolumn{2}{|c|}{ 90-th } \\
\hline & & 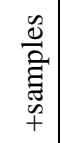 & a & $\begin{array}{l}\frac{\tilde{d}}{0} \\
\stackrel{2}{\Xi} \\
\overline{0} \\
+ \\
+\end{array}$ & बे & $\begin{array}{l}0 \\
\hat{0} \\
\text { : } \\
000 \\
+\end{array}$ & $\ddot{\theta}$ \\
\hline 1 & Klosanthin 20\% & 17 & 37.78 & 5 & 11.11 & 0 & 0 \\
\hline 2 & Alben granules & 11 & 24.45 & 2 & 4.45 & 2 & 4.45 \\
\hline 3 & Closaverm & 3 & 6.67 & 0 & 0 & 0 & 0 \\
\hline 4 & Santomectin & 2 & 4.45 & 0 & 0 & 0 & 0 \\
\hline 5 & Albendozole & 6 & 13.33 & 3 & 6.67 & 1 & 2.22 \\
\hline 6 & $\begin{array}{l}\text { No deworming - } \\
\text { control group }\end{array}$ & 45 & 100 & 45 & 100 & 45 & 100 \\
\hline
\end{tabular}

Table 4. Comparative characteristics of anthelmintic drugs recommended for cattle infected with strongilates of the gastrointestinal tract.

\begin{tabular}{|c|c|c|c|}
\hline Drug name & Doze & Cost & $\begin{array}{c}\text { Cost of } \\
1 \text { dose }\end{array}$ \\
\hline \multicolumn{4}{|c|}{ A wide-spectrum medication } \\
\hline Alben tablets & 1 tab. $/ 35 \mathrm{~kg}$ & 1 tab. $-10 \mathrm{rub}$ & $130 \mathrm{rub}$ \\
\hline Klosanthin $20 \%$ & $1.25 \mathrm{ml} / 50 \mathrm{~kg}$ & $100 \mathrm{ml}-685 \mathrm{rub}$ & $77 \mathrm{rub}$ \\
\hline Ivermec & $1 \mathrm{ml} / 50 \mathrm{~kg}$ & $50 \mathrm{ml}-193 \mathrm{rub}$ & $35 \mathrm{rub}$ \\
\hline Novomek & $1 \mathrm{ml} / 50 \mathrm{~kg}$ & $100 \mathrm{ml}-420 \mathrm{rub}$ & $38 \mathrm{rub}$ \\
\hline Albendozole & $15 \mathrm{ml} / 50 \mathrm{~kg}$ & $11 .-625 \mathrm{rub}$ & $84 \mathrm{rub}$ \\
\hline
\end{tabular}

According to the results of our studies in the case of nematode monoinvasion, the most effective antiparasitic drugs are Klosanthin $20 \%$ (the cost of one dose per animal is 77 rubles) and Ivermectins (the cost of deworming per animal does not exceed 40 rubles).

Table 5. Infestation degree of cattle infected with strongilates of the gastrointestinal tract after deworming $(n=45)$.

\begin{tabular}{|c|c|c|c|c|c|c|c|}
\hline \multirow[b]{3}{*}{$\begin{array}{c}\text { Group } \\
\text { № }\end{array}$} & \multirow[b]{3}{*}{ Drug name } & \multicolumn{6}{|c|}{ Research time, days } \\
\hline & & \multicolumn{2}{|c|}{ 15-th } & \multicolumn{2}{|c|}{ 30-th } & \multicolumn{2}{|c|}{ 90-th } \\
\hline & & 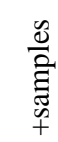 & $\begin{array}{l}0 \\
\theta\end{array}$ & 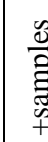 & $a^{\circ}$ & 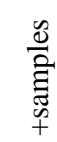 & $\begin{array}{l}\circ \\
\theta\end{array}$ \\
\hline 1 & Alben tablets & 21 & 46.7 & 15 & 33.3 & 11 & 24.5 \\
\hline 2 & Klosanthin $20 \%$ & 2 & 4.5 & 0 & 0 & 0 & 0 \\
\hline 3 & Ivermec & 3 & 6.67 & 1 & 2.2 & 0 & 0 \\
\hline 4 & Novomek & 2 & 4.45 & 0 & 0 & 0 & 0 \\
\hline 5 & Albendozole & 6 & 13.33 & 3 & 6.67 & 1 & 2.22 \\
\hline 6 & $\begin{array}{l}\text { No deworming - } \\
\text { control group }\end{array}$ & 45 & 100 & 45 & 100 & 45 & 100 \\
\hline
\end{tabular}

Table 6. Infestation degree of cattle with associative invasion: fasciola + strongilates of the gastrointestinal tract after deworming $(n=45)$.

\begin{tabular}{|c|c|c|c|c|c|c|c|}
\hline \multirow[b]{3}{*}{$\begin{array}{l}\text { Group } \\
\text { № }\end{array}$} & \multirow[b]{3}{*}{ Drug name } & \multicolumn{6}{|c|}{ Research time, days } \\
\hline & & \multicolumn{2}{|c|}{ 15-th } & \multicolumn{2}{|c|}{ 30-th } & \multicolumn{2}{|c|}{ 90-th } \\
\hline & & 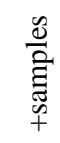 & $\stackrel{0}{\hat{\theta}}$ & 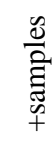 & $\begin{array}{l}0 \\
\hat{\theta}\end{array}$ & 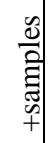 & 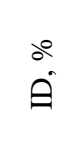 \\
\hline 1 & Klosanthin $20 \%$ & 14 & 31.11 & 14 & 31.11 & 3 & 6.67 \\
\hline 2 & Albendozole & 23 & 51.11 & 18 & 40 & 9 & 20 \\
\hline 3 & $\begin{array}{l}\text { No deworming - } \\
\text { control group }\end{array}$ & 45 & 100 & 45 & 100 & 45 & 100 \\
\hline
\end{tabular}

The results in the table show that Albene is an ineffective tool against strongilates of the gastrointestinal tracts, the infestation degree, in this case, was $75.5 \%$, perhaps this is due to the fact that this remedy has already been used in the studied farms for several years.

In the case of associative invasion of cattle with fasciolas and strongilates of the gastrointestinal tract, two drugs were used: Albendozole and Klosanthin $20 \%$ (table 6).

The therapeutic efficacy in animals invaded by associations of detected helminths was determined by Klosanthin $20 \%$ and Albendozole, and it was identified that the extenseffectivity does not exceed $93.3 \%$.

\section{Discussion}

Currently, one of the pressing issues in the work of any livestock enterprise is the welfare of the economy in relation to parasitic diseases. In the farms of the Udmurt Republic, the most common endoparasites of cattle are Fasciola hepatica, Chabertia ovina and Haemonchus contortus and their association. To solve this problem, a competent approach to the prevention and treatment of helminthiases is necessary. The range of antiparasitic drugs in the veterinary market is constantly replenished. It is important to make the right choice both on the basis of studying an epizootic situation, including the presence of components of parasitocenosis in animals, and taking into account the cost of drugs. 
Different drugs were used in the experiments, because the choice of antiparasitic drugs for each houshold is individual and it is necessary to focus not only on cost, but also pay attention to the following indicators:

- the minimum period of elimination with milk of lactating cows, this would allow using it for processing of the entire livestock simultaneously;

- to be effective against associations of infestations, since according to the data of our studies, the presence of mixed infections has been established in farms;

- to be effective after a single treatment;

- to be technologically advanced, that is, to have a simple method of application, not to require mandatory qualified training.

It is necessary to take into account climatic conditions, so the most favorable climatic conditions for the development of $F$. hepatica were observed in the central Uvinsky region, where the invasion intensity reaches up to $49.22 \%$.

At the same time, the degree of infection with geohelminths (Chabertia ovina, Haemonchus contortus) is more than 2.5 times lower. In case of association between fasciola and strongilates of the gastrointestinal tract, there was a slightly different picture: the minimum percentage of infection was observed in the northern Kes region and amounted to $5.59 \%$, and the largest number of infected animals (almost $22 \%$ ) was in the southern Malopurginsky district.

It is necessary to take into account the development of parasite resistance to the effect of chemotherapeutic drugs. Currently, this situation has grown from being a veterinary problem to an economic one.

The studies have shown that the wide-spectrum antiparasitic drug Klosantin $20 \%$, in our opinion, maximally meets the specified criteria for the fight against fasciolia, strongylates of the digestive tract and their association.

\section{Conclusion}

The high degree of cattle infection in various regions of the Udmurt Republic with fasciolosis and strongilatosis of the gastrointestinal tract is due to optimal climatic conditions for the regular transmission of the pathogen to susceptible animals.

Among monoinvasions, the dominant position is taken by strongilatoses of the gastrointestinal tract. The degree of infection is ranged from 33.07 to $59.59 \%$. The high degree of invasion can be explained by the fact that, firstly: the population of adult animals (cows, heifers) in the strongilates epizootic process is gastrointestinal tract as the primary source of invasion pathogen, and secondly: the biological cycle of the pathogen depends on conditions of environment, which are quite favorable for geohelminthes in the Republic.

The most favorable climatic conditions for the development of $F$. hepatica were observed in the central Uvinsky region, where the invasion intensity reaches up to $49.22 \%$. The smallest percentage of adult livestock infection $(16.77 \%)$ has been recorded in the northern Kez district of the Udmurt Republic.

In case of association between fasciola and strongilates of the gastrointestinal tract, there was a slightly different picture: the minimum percentage of infection was observed in the northern Kes region and amounted to $5.59 \%$, and the largest number of infected animals (almost $22 \%$ ) was in the southern Malopurginsky district.

Analyzing the effectiveness of the studied anthelmintic drugs, we found that Klosantin $20 \%$ at a dose of 1 is the optimal drug in terms of efficacy and cost for monoinvasions (ID - $100 \%$ ) with fasciola or strongilates of the gastrointestinal tract, and their association (ID - 93.3\%), 1.25ml / $50 \mathrm{~kg}$ of animal weight.

\section{References}

1. M.E. Mkrtchyan, E.S. Klimova, Veterinary bulletin, 1(64), 23-25 (2013)

2. L.W. Wamae, J.A. Hammond, L.J.S. Harrison, J.A. Onyango-Abuje, Trop. Animal Health and Product., 1, 23-30 (1998)

3. M.E. Mkrtchyan, E.I. Troshin, E.S. Kalinina, Issues of statutory regulation in veterinary, 1, 109-110 (2013)

4. N. Maingi, R.O. Otieno, E.H Weda., V.M. Gichohi, Veter. Res. Communicat., 7, 543-552 (2002)

5. M. Meaney, I. Fairweather, G. Brennan, P. Ramasamy, P. Subramanian, Parasitol. Res., 4, 315-325 (2002)

6. M.B. Musaev, M.V. Milenina, I.A. Arkhipov, S.S. Halikov, F.S. Mikhaylitsyn, A.I. Varlamova, Rus. Parasitolog. journal, 3, 271-276 (2017)

7. R.T. Safiullin, A.M. Ustinov, Veter., 4, 17-20 (2010)

8. M.J. Stear, M. Doligalska, K. Donskow-schmelter, Parasitol., 2, 151 (2007)

9. G. Stepek, D.J. Buttle, I.R. Duce, A. Lowe, J.M., Parasitol., 2, 203-211 (2005)

10. D. Traversa, J. von Samson-Himmelstjerna, Small Ruminant Res., 135, 75-80 (2016) 